\title{
Persistent and Transient Distal Renal Tubular Acidosis with Bicarbonate Wasting
}

\author{
ERNST P. LEUMANN AND BEAT STEINMANN
}

Divisions of Nephrology and Metabolism, Universitv Children's Hospital, Zürich, Switzerland

\section{Extract}

Bicarbonate titration studies were performed on two patients with bicarbonate wasting distal renal tubular acidosis (RTA; patients I and 2$)$ and on three patients $(3,4$, and 5$)$ with classic distal RTA. Daily requirements of alkali were $4.5 \mathrm{mEq} / \mathrm{kg}$ body wt in patient $I$, a 3-vear-old boy, and $16 \mathrm{mEq} / \mathrm{kg}$ in patient 2, a 5-month-old male infant. In contrast, only $1.5-2 \mathrm{mEq} / \mathrm{kg} / 24 \mathrm{hr}$ alkali were required in the three patients with classic distal RTA (age $81 \frac{1}{2}-22$ years). Patient $l$ had glucose-6-phosphate dehydrogenase deficiency and patient 3 had inner ear deafness as an associated anomaly. In patient 2, the acidification defect was transient.

Mean fractional excretion of bicarbonate $\left(\mathrm{C}_{\mathrm{HC}()_{3}}{ }^{-} / \mathrm{C}_{\mathrm{in}}\right) \times 100$ at a plasma concentration of $\mathrm{HCO}_{3}$ below $20 \mathrm{mmol} / \mathrm{liter}$ was $5.1 \%$ in patient $1,11.6 \%$ in patient 2 , and $1.7 \%$ in patients $3-5$. Minimal urine $\mathrm{pH}$ during the study was 7.38 in patient $1,7.66$ in patient 2 , and 6.78-6.97 in the other patients. Values of net acid excretion at plasma $\mathrm{HCO}_{3}=16 \mathrm{mmol} /$ liter were strongly negative in patients $l$ and $2(-75$ and $-195 \mu \mathrm{mol} / 100 \mathrm{ml}$ glomerular filtrate (GF), respectively) but slightly positive in the three patients with classic RTA $(+3$ to $+20 \mu \mathrm{mol} / 100 \mathrm{ml} \mathrm{GF})$.

The two patients with bicarbonate wasting distal RTA were thus clearly separated from the group of patients with classic distal RTA.

\section{Speculation}

Bicarbonate wasting in distal RTA could be the result of an additional defect of the proximal nephron or of a distal defect which is more severe than in classic distal RTA. The transient variant might correspond to Lightwood's syndrome of "transient infantile RTA."

Renal tubular acidosis is a clinical syndrome characterized by inability of the renal tubules to excrete adequate amounts of acid in the urine (in the absence of uremia). Two different types have been distinguished on clinical and physiologic grounds. In the classic distal type (type I), first described by Butler et al. (4) and later by Albright et al. (1), clinical manifestations usually begin in the second year of life and nephrocalcinosis is often present. The urinary $\mathrm{pH}$ never falls below 6.2. Urinary losses of bicarbonate are low, however, and metabolic acidosis is corrected easily by oral doses of alkali (1-2 mEq/ $\mathrm{kg}$ body $\mathrm{wt} / 24 \mathrm{hr}$ ), corresponding roughly to the amount of nonvolatile acid generated daily. The second, of proximal type (type II) of RTA has been characterized more recently $(32,33)$. Excretion of bicarbonate in the urine is considerable, but normal urinary acidification $(\mathrm{pH}<5.0)$ is achieved at moderate to severe degrees of acidosis. This defect is usually secondary and is, with one exception (33), associated with other functional disorders of the proximal tubule.

Although most cases with RTA can be readily classified into the distal or the proximal form of the disorder, there are patients who do not correspond entirely to either type. McSherry et al. (23) have recently reported two male infants with apparent classic distal RTA but considerable urinary excretion of bicarbonate which had led to clinical manifestation of metabolic acidosis at an extremely early age. Three other patients have since been reported by Rodriquez Soriano et al. (34). We have performed bicarbonate titration studies in two patients with bicarbonate wasting distal RTA, one of whom had a transient acidification defect. Results of the studies are compared with those obtained in three patients with classic distal RTA.

\section{METHODS}

\section{BICARBONATE TITRATION STUDY}

Treatment with alkali was interrupted either $32-40 \mathrm{hr}$ (patients $I$ and 2 ) or 4 days (patients 3-5) before the study, resulting in spontaneous occurrence of metabolic acidosis. The patients were fasting but were allowed to drink slightly sugared fluids throughout the study. Urine was collected through an indwelling urethral catheter and the bladder emptied by suprapubic pressure. Free flowing blood was obtained through an indwelling needle placed in a superficial cubital vein for blood gas analysis and chemical determinations. In two instances (first study in patient $l$ and in patient 2), however, blood gas analysis was performed on arterialized capillary blood. After priming with polyfructosan (42) $(0.1$ $\mathrm{g} / \mathrm{kg}$ body weight) and $p$-aminohippurate (PAH, $8 \mathrm{mg} / \mathrm{kg}$ ), a solution containing $10-12 \%$ polyfructosan, $2-2.4 \% \mathrm{PAH}$, and $0.36-0.45 \%$ saline was infused at a constant rate of $0.4 \mathrm{ml} / \mathrm{kg}$ (patients 4 and 5) or $0.8-1.0 \mathrm{ml} / \mathrm{kg} / \mathrm{hr}$ throughout the study. Measured plasma concentrations were $38 \cdots 86 \mathrm{mg} / 100 \mathrm{ml}$ for polyfructosan and $1.9-3.8 \mathrm{mg} / 100 \mathrm{ml}$ for PAH. After an initial control clearance period, sodium bicarbonate $(0.3 \mathrm{~mol} / \mathrm{liter})$ was infused at an hourly rate of $0.9 \mathrm{mmol} / \mathrm{kg}$ (patients 4 and 5). 1.4 $\mathrm{mmol} / \mathrm{kg}$ (patient 3 ), or $2-2.2 \mathrm{mmol} / \mathrm{kg}$ (patients $l$ and 2 ). The rate of bicarbonate infusion was increased by a factor of $1.4-2$ at a plasma concentration of $\mathrm{HCO}_{3}{ }^{-}$of $19.2 \mathrm{mmol} /$ liter (patient 2) or $22 \mathrm{mmol} /$ liter except in patient 1 . In the first study of patient $l$, glomerular filtration rate (GFR) was estimated by the clearance of creatinine.

\section{LABORATORY METHODS}

$\mathrm{pH}$ and $\mathrm{pCO}_{2}$ in blood were measured at $37^{\circ}$ with a microanalyzer (AVL-936). Actual plasma $\mathrm{HCO}_{3}{ }^{-}$was calculated from Henderson-Hasselbalch's equation: values employed for $\mathrm{pK}$ and $\alpha$ in serum were 6.10 and 0.0301 .

Urine was not collected under oil but processed immediately. Measurements of $\mathrm{pH}$ and titrations for the difference between titratable acid and bicarbonate ( $\left.\mathrm{TA}-\mathrm{HCO}_{3}\right)$ and for ammonium were carried out at room temperature to an end-point of 7.40 using a pH meter (Metrohm E $300 \mathrm{~B}$ ) with autotitrator. The difference ( $\mathrm{TA}-\mathrm{HCO}_{3}{ }^{-}$) was measured in a single step according to the method of Jorgenson (18) by boiling $5 \mathrm{ml}$ urine with $5 \mathrm{ml} 0.1 \mathrm{M}$ hydrochloric acid before titration with sodium hydroxide. Ammonium was subsequently measured by formol titration (18) and in some studies (patients $l$ and 2 ) in addition by a microdiffusion method (9): the results of both methods agreed within narrow limits. Total $\mathrm{CO}_{2}$ content $\left(\mathrm{tCO}_{2}\right)$ in urine was determined by a Natelson microgasometer (27). Urinary bicarbonate concentration 
was calculated from urinary $\mathrm{pH}$ and $\mathrm{tCO}_{2}$ by Henderson-Hasselbalch's equation; $\mathrm{pK}$ was taken as

$$
6.33-0.5 \sqrt{\left(\mathrm{Na}^{+}\right)+\left(\mathrm{K}^{+}\right)(16)} .
$$

Sodium and potassium were measured by flame photometry (IL model 143), chloride by coulometry (Buchler-Cotlove), calcium by atomic absorption, polyfructosan by an anthrone method (31), PAH by a modification of the method of Bratton and Marshall (31), and creatinine in serum after absorption to Lloyd's reagent (41)

\section{CASE REPORTS}

Clinical findings and results of renal function tests are summarized in Tables 1 and 2.

Patient 1: PG, born April 2, 1970. This patient, of Italian origin, was first hospitalized at the age of 6 weeks with 3 weeks' history of vomiting, constipation, and failure to thrive. On admission he was pale, dehydrated, and severely acidotic ( $\mathrm{pH}$ in blood 6.98, plasma $\mathrm{HCO}_{3}-3.3 \mathrm{mmol} /$ liter). Serum electrolytes were $\mathrm{Na}^{+} 151, \mathrm{~K}+5.0$, and $\mathrm{Cl}^{-} 130 \mathrm{mmol} /$ liter. After rehydration, body weight was 3.03 $\mathrm{kg}$ (at birth, $3.3 \mathrm{~kg}$ ). Urinary $\mathrm{pH}$ never fell below 7.13 even at plasma $\mathrm{HCO}_{3}^{-}=7.8 \mathrm{mmol} /$ liter. Urinalysis and intravenous pyelogram were normal, but bilateral nephrocalcinosis was seen as early as 7 weeks of age. There was neither glucosuria nor aminoaciduria. Urinary calcium excretion was normal except during severe metabolic acidosis $(13.4 \mathrm{mg} / \mathrm{kg} / 24 \mathrm{hr})$. Excre-

Table 1. Clinical findings in five patients with distal renal tubular acidosis

\begin{tabular}{lcccc}
$\begin{array}{c}\text { Patient } \\
(\text { sex }\end{array}$ & $\begin{array}{c}\text { Age at } \\
\text { study, yr }\end{array}$ & $\begin{array}{c}\text { Nephro- } \\
\text { calcin- } \\
\text { osis }\end{array}$ & $\begin{array}{c}\text { Associated } \\
\text { anomaly }\end{array}$ & $\begin{array}{c}\text { Alkali } \\
\text { requirements, } \\
\mathrm{mmol} / \mathrm{kg} / \\
24 \mathrm{hr}\end{array}$ \\
\hline$I(\mathrm{M})$ & $32 / 12$ & + & $\begin{array}{c}\text { Glucose-6-P } \\
\text { dehydrogenase } \\
\text { deficiency }\end{array}$ & 4.5 \\
$2(\mathrm{M})$ & $5 / 12$ & - & & $16 \rightarrow 0$ \\
$3(\mathrm{~F})$ & $86 / 12$ & + & $\begin{array}{c}\text { Inner ear } \\
\text { deafness }\end{array}$ & 2.0 \\
$4(\mathrm{M})$ & $14 \% / 12$ & + & & 1.5 \\
$5(\mathrm{M})$ & 22 & + & & 2.0 \\
\hline
\end{tabular}

tion of citrate was low during acidosis $(0.6-1.6 \mathrm{mg} / \mathrm{kg} / 24 \mathrm{hr}$, normal $4-12(36))$ and slightly higher after its correction $(2.5-4.4)$. Further studies revealed complete absence of erythrocyte glucose6-phosphate dehydrogenase (G-6-PD). Anemia (hemoglobin 6.4 $\mathrm{g} / 100 \mathrm{ml}$, reticulocyte count $9.6 \%$ ), for which the patient required two blood transfusions, was present only initially. It is suggested that severe metabolic acidosis on admission precipitated hemolysis.

The infant made a good recovery after therapy with bicarbonate $(6 \mathrm{mmol} / \mathrm{kg} / 24 \mathrm{hr}, 3 \mathrm{mmol} / \mathrm{kg}$ as the sodium and $3 \mathrm{mmol} / \mathrm{kg}$ as the potassium salt); the daily dosage has since been reduced to 4.5 $\mathrm{mmol} / \mathrm{kg}$. Withdrawal of treatment continued to result in reappearance of severe acidosis. At age $47 / 12$, plasma bicarbonate was $9.2 \mathrm{mmol} /$ liter (urinary $\mathrm{pH} 7.18$ ) after 3 days off therapy, and maximum urinary concentration was $380 \mathrm{mOsm} / \mathrm{kg}$. Height was $100 \mathrm{~cm}$ ( $3 \mathrm{rd}$ centile) and weight $13.5 \mathrm{~kg}$ (below $3 \mathrm{rd}$ centile). The father is hemizygous, the mother heterozygous and the sister homozygous for the G-6-PD deficiency. Blood gas analysis is normal in all of them. After an oral acid load with $\mathrm{NH}_{4} \mathrm{Cl}$, urine $\mathrm{pH}$ fell to 4.90 in the father and to 4.85 in the sister.

Patient 2: $Z D$, born August 28, 1973. The clinical course is shown in Figure 1. This boy was admitted at 4 months of age because of constipation, vomiting, and failure to thrive. Weight was $4.750 \mathrm{~g}(<3 \mathrm{rd}$ centile) and length $62.5 \mathrm{~cm}$ ( 50 th centile). Positive clinical findings were tachypnea $(45 / \mathrm{min})$ and moderate dehydration. Urinary $\mathrm{pH}$ was high (7.13) despite marked acidosis $\left(\mathrm{pH}\right.$ in blood 7.205, $\mathrm{pCO}_{2} 20 \mathrm{~mm} \mathrm{Hg}$, actual $\mathrm{HCO}_{3}^{-} 7.7$ $\mathrm{mmol} /$ liter). Serum values were: $\mathrm{Na}+132, \mathrm{~K}^{+} 4.5, \mathrm{Cl}^{-} 123$ $\mathrm{mmol} /$ liter; calcium: total $12.7 \mathrm{mg} / 100 \mathrm{ml}$, ionized fraction 6.83 $\mathrm{mg} / 100 \mathrm{ml}$, phosphorus $4.6 \mathrm{mg} / 100 \mathrm{ml}$, alkaline phosphatase 104 IU, total protein $6.1 \mathrm{~g} / 100 \mathrm{ml}$; parathyroid hormone (PTH) (43) was not measurable $(<5 \mathrm{ng} / \mathrm{ml})$. There was a significant renal concentration defect $(515 \mathrm{mOsm} / \mathrm{kg})$. Urinalyses were normal and urine cultures obtained by suprapubic puncture were negative. The following laboratory examinations were done and found to be normal: tubular reabsorption of amino acids and of phosphate. urinary excretion of calcium $(4 \mathrm{mg} / \mathrm{kg} / 24 \mathrm{hr})$, and of heavy metals $(\mathrm{Hg}, \mathrm{Cu}, \mathrm{Cd}, \mathrm{Pb})$; protein electrophoresis, immunoglobulins, and ceruloplasmin in serum; cystine content in leucocytes; bone marrow; split lamp examination of the cornea: and intravenous pyelogram. No nephrocalcinosis was present radiologically. Bone $\mathrm{x}$-ray showed slight osteoporosis. Urinary excretion of citrate was low $(0.7 \mathrm{mg} / \mathrm{kg} / 24 \mathrm{hr})$.

The patient had received only 400 units of vitamin D/24 hr during the preceding 6 weeks. Because of suspected urinary tract infection, therapy with ampicillin was initiated 6 weeks before admission but had to be discontinued because of an allergic rash.

Table 2. Results of clearance studies

\begin{tabular}{|c|c|c|c|c|c|c|}
\hline \multirow[b]{2}{*}{ Patient } & $\mathrm{C}_{\mathrm{in}}{ }^{1}$ & $\mathrm{C}_{\mathrm{PAH}}{ }^{1}$ & \multirow{2}{*}{$\begin{array}{l}\text { Minimal urine } \\
\mathrm{pH} \text { (at study) }\end{array}$} & \multicolumn{2}{|c|}{$\frac{\mathrm{C}_{\mathrm{HCO} 3}}{\mathrm{C}_{\mathrm{in}}} \times 100^{2}$} & \multirow{2}{*}{$\begin{array}{l}\text { Net acid excretion, }{ }^{3} \\
\mu \mathrm{mol} / 100 \mathrm{ml} \mathrm{GF}\end{array}$} \\
\hline & \multicolumn{2}{|c|}{$\mathrm{ml} / \mathrm{min} / 1.73 \mathrm{~m}^{2}$} & & Mean & Range & \\
\hline 1 & $106^{a}$ & $525^{a}$ & 7.38 & 5.1 & $3.8-6.3$ & -75 \\
\hline 2 & $98^{b}$ & $305^{b}$ & 7.66 & 11.6 & $9.1 \cdot 15.0$ & -195 \\
\hline 3 & $82^{c}$ & $436^{c}$ & 6.78 & 1.6 & $1.1-2.8$ & +3 \\
\hline 4 & $113^{c}$ & $520^{\circ}$ & 6.77 & 1.7 & $1.3 \cdots 2.1$ & $+4^{4}$ \\
\hline 5 & $74^{d}$ & $452^{d}$ & 6.97 & 1.8 & $1.0-2.7$ & +20 \\
\hline
\end{tabular}

\footnotetext{
${ }^{1}$ Normal values according to age in milliliters per min per $1.73 \mathrm{~m}^{2}$ (from Reference 22)

${ }^{a}$ Children 3-8 years: $\mathrm{C}_{\text {in }}=131 \pm 26, \mathrm{C}_{\mathrm{PAH}}=659 \pm 115$.

${ }^{b}$ Infants 6-12 months: $\mathrm{C}_{\text {in }}=77 \pm 14, \mathrm{C}_{\mathrm{PAH}}=352 \pm 73$.

c Children 8-14 years: $\mathrm{C}_{\mathrm{in}}=120 \pm 20, \mathrm{C}_{\text {pan }}=631 \pm 98$.

${ }^{d}$ Male adults: $C_{\text {in }}=125 \pm 19, C_{\text {pah }}=655 \pm 98$.

${ }^{2}$ At plasma $\mathrm{HCO}_{3}{ }^{-}<20 \mathrm{mmol} /$ liter.

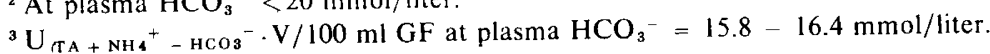

${ }^{4}$ At plasma $\mathrm{HCO}_{3}^{-}=18.2 \mathrm{mmol} /$ liter.
} 


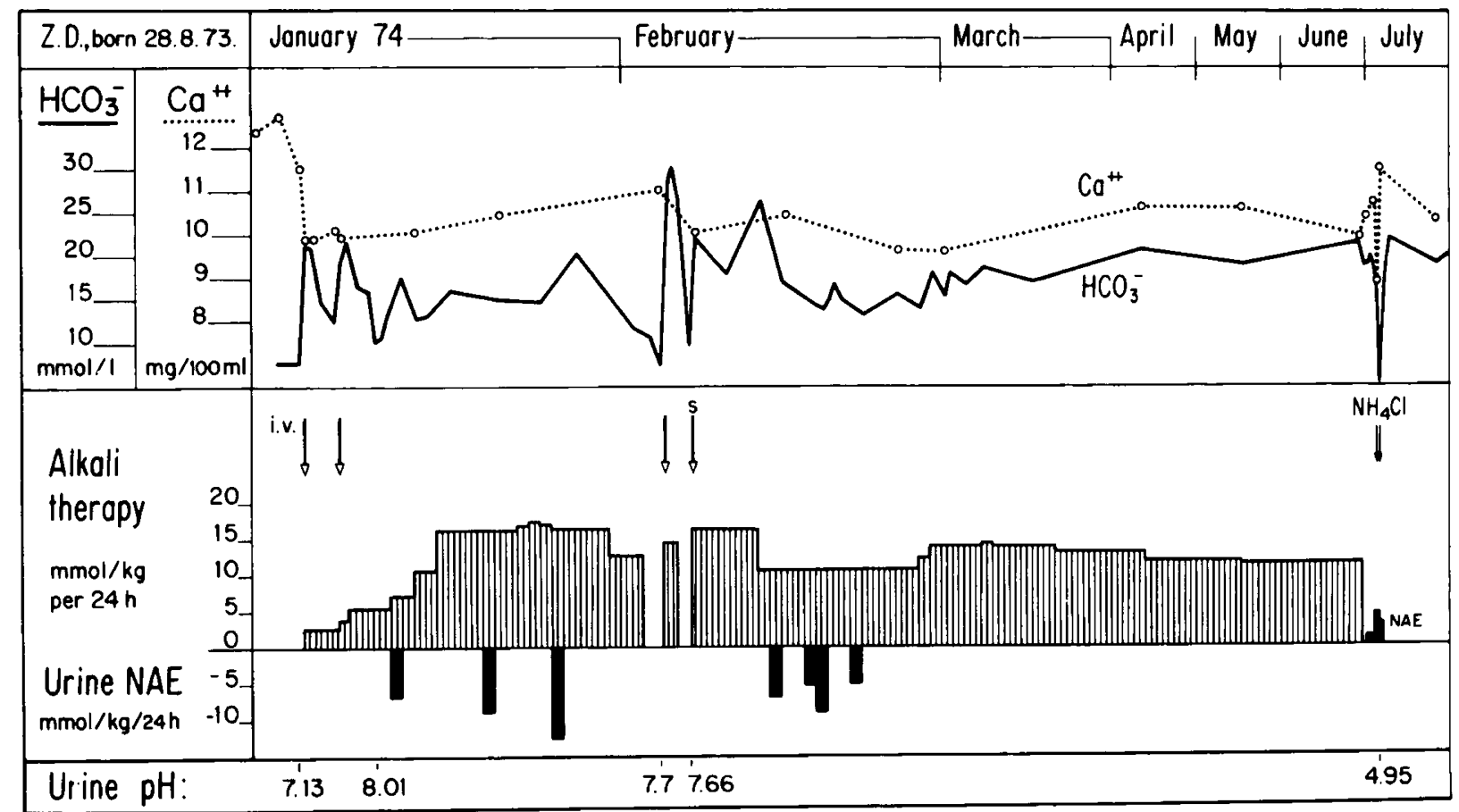

Fig. 1. Transient distal RTA with bicarbonate wasting (patient 2). $\mathrm{HCO}_{3}^{-}:$actual bicarbonate (blood); $\mathrm{Ca}^{++}$: total calcium (serum). In addition to oral administration of alkali, bicarbonate was infused intravenously (arrows). s: time of the bicarbonate titration study: NAE: net acid excretion.

No blood gas analysis was performed at that time. Eosinophilia $\left(16 \%\right.$, total white blood cell count $\left.13,900 / \mathrm{mm}^{3}\right)$ was present at admission and later disappeared.

Despite very large doses of alkali $(16 \mathrm{mmol} / \mathrm{kg} / 24 \mathrm{hr}$, twothirds as sodium and one-third as potassium citrate) acidosis was not fully corrected. Yet there was a rapid clinical improvement; serum calcium and PTH $(17 \mathrm{ng} / \mathrm{ml})$ returned to normal levels. $\checkmark$ alues of net acid excretion in urine were strongly negative during the first 2 months in spite of persisting acidosis (Fig. 1). The measured values corresponded grossly to the amount administered by mouth; this indicates that the salt was really absorbed. Interruption of therapy after 1 month resulted in rapid recurrence of severe acidosis (after $36 \mathrm{hr}$, plasma $\mathrm{HCO}_{3}^{-}$was $7.9 \mathrm{mmol} / \mathrm{liter}$; $\mathrm{pH}$ in blood 7.15 , in urine 7.70 ). The bicarbonate titration study was performed 3 days later. Hydrochlorothiazide $(18.8 \mathrm{mg} / 24 \mathrm{hr}$ for 1 week) had no effect on acidosis.

The patient was discharged from the hospital at the age of 6 months (weight $6.2 \mathrm{~kg}=3$ rd centile). He was followed up regularly and was re-admitted 4 months later for re-evaluation. Quite unexpectedly, acidosis did not reappear after therapy was discontinued. Renal concentration ability was normal $(880 \mathrm{mOsm} / \mathrm{kg})$. Acidosis was induced by oral administration of $\mathrm{NH}_{4} \mathrm{Cl}(6 \mathrm{mmol} / \mathrm{kg}$ on 2 consecutive days). Urine $\mathrm{pH}$ was still 5.74 at plasma $\mathrm{HCO}_{3}{ }^{-}=$ $15.3 \mathrm{mmol} /$ liter but was 4.95 at $\mathrm{HCO}_{3}{ }^{-}=5.5 \mathrm{mmol} /$ liter. Only a small dose of alkali $(3.5 \mathrm{mmol} / \mathrm{kg})$ was then given intravenously, resulting in plasma $\mathrm{HCO}_{3}{ }^{-}$of $11.9 \mathrm{mmol} /$ liter. Thereafter, acidosis cleared spontaneously within 2 days. The patient has done well since then without any therapy. At the age of $14 / 12$, weight was $9.4 \mathrm{~kg}$ ( 3 rd centile), and urine $\mathrm{pH}$ was 5.30 at plasma $\mathrm{HCO}_{3}{ }^{-}=$ $16.8 \mathrm{mmol} /$ liter after an oral acid load. Urinary excretion of citrate was now normal $(10 \mathrm{mg} / \mathrm{kg} / 24 \mathrm{hr})$. Renal function is normal in the parents and the sister.

Patient 3: AR, born February 9, 1965. This girl was first hospitalized at the age of 4 months because of anorexia, constipation, and failure to thrive. At that time, $\mathrm{tCO}_{2}$ was $8 \mathrm{mmol} /$ liter and urine $\mathrm{pH}$ 6-7.5 (measured by indicator paper). She improved rapidly after administration of alkali. At 11 months of age, minimal urine $\mathrm{pH}$ was $6.5\left(\mathrm{tCO}_{2}=14 \mathrm{mmol} /\right.$ liter $)$. Slight nephrocalcinosis was first seen on $x$-ray at age $17 / 12$ and has progressed since, but therapy with sodium and potassium citrate ( 1.4 and $0.6 \mathrm{mmol} / \mathrm{kg} / 24 \mathrm{hr}$, respectively) was not taken regularly until 6 years of age. Inner ear deafness was diagnosed at 26/2. Highest recorded relative density in the urine was 1.012 . At $9 \% 12$, height was $123 \mathrm{~cm}$ and weight $23.5 \mathrm{~kg}$ (both between $3 \mathrm{rd}$ and $10 \mathrm{th}$ centile).

One sister died at 10 months of age (cause unknown), three older siblings and the parents are healthy.

Patient 4: GPa., born November 10, 1957. Renal calcifications were detected in this Italian patient at 7 years of age during work-up for polydipsia. Distal RTA was diagnosed in 1966 (plasma $\mathrm{HCO}_{3}{ }^{-}=17.3 \mathrm{mmol} /$ liter urine $\mathrm{pH} 6.4$ ). There were no signs of rickets. Highest urinary concentration was $345 \mathrm{mOsm} / \mathrm{kg}$. Continuous therapy with sodium bicarbonate (2.5, later 1.5 $\mathrm{mmol} / \mathrm{kg} / 24 \mathrm{hr}$ ) resulted in disappearance of initial hypercalciuria $(8.3 \mathrm{mg} / \mathrm{kg} / 24 \mathrm{hr})$ and in general improvement. The parents are first cousins. Both are healthy as is the patient's brother.

Patient 5 (44): $B W$, born January 15, 1950. Florid rickets were discovered at the age of $24 / 12$, at which time length was $85.5 \mathrm{~cm}$ and weight $11.5 \mathrm{~kg}$ (both below $3 \mathrm{rd}$ centile). Therapy with high doses of vitamin $D(15 \mathrm{mg} 12$ times in a period of 18 months $)$ resulted in cure of the rickets. The diagnosis of RTA was made at the age of $5 \% 12$ years $\left(\mathrm{tCO}_{2}\right.$ in blood $=13.5 \mathrm{mmol} /$ liter: urine $\mathrm{pH} 6.8$, highest relative density 1.011$)$. $x$ - Rays showed moderate nephrocalcinosis. Urinary excretion of citrate was diminished $(0.3-1.1 \mathrm{mg} / \mathrm{kg} / 24$ hr). Continuous therapy with sodium bicarbonate (3, later 2 $\mathrm{mmol} / \mathrm{kg} / 24 \mathrm{hr}$ ) resulted in rapid clinical improvement and prevented re-appearance of rickets. The patient has recently passed several urinary calculi. Both siblings and the parents acidify urine normally.

\section{RESULTS}

Results of clearance studies are summarized in Table 2. Values of GFR and of effective renal plasma flow $\left(\mathrm{C}_{\mathrm{PAH}}\right)$ were normal in patient 2 and borderline normal in patients $l$ and 4 . The values were definitely decreased in patients 3 and 5 , probably as a consequence of irreversible kidney damage caused by nephrocalcinosis. 


\section{BICARBONATE EXCRETION}

Even at low plasma concentrations bicarbonate was present continuously in urine in all five patients (Figs. 2 and 3). Excretion of bicarbonate, expressed in micromoles per $100 \mathrm{ml} \mathrm{GF}$, was highest in patient 2 (mean 167, range 126-203, $n=9$ at concentration of plasma bicarbonate between 10.9 and $21.6 \mathrm{mmol} / \mathrm{liter})$. In patient $l$ it increased from 34 to $78 \mu \mathrm{mol} / 100 \mathrm{ml} \mathrm{GF}$ (at concentrations of bicarbonate rising from 10.4 to $16.9 \mathrm{mmol} /$ liter) and exceeded 100 $\mu \mathrm{mol} / 100 \mathrm{ml} \mathrm{GF}$ at plasma bicarbonate $\geq 17.3 \mathrm{mmol} /$ liter (range $114-154$ in the first, $102-120$ in the second study; see Table 3 and Fig. 3).

In contrast, excretion of bicarbonate in the three patients with classic distal RTA was considerably lower. The mean value for patients 3-5 (at plasma bicarbonate $<24 \mathrm{mmol} /$ liter) was 34.0 $\mu \mathrm{mol} / 100 \mathrm{ml} \mathrm{GF}(n=26)$; mean in patient $3,29.3$ (range 18-48); in patient 4, $34.8(26-49)$; in patient 5, 38.5 (19-55). The difference between the mean bicarbonate excretion in patients $l$ and 2 and that in patients $3-5$ is statistically significant $(P<0.001)$. The mean percentage of filtered bicarbonate excreted in the urine $\left(\mathrm{C}_{\mathrm{H}\left(\mathrm{C}_{3}\right.}{ }^{-}\left(\mathrm{C}_{\mathrm{in}}\right) \times 100\right.$ at concentrations of bicarbonate in plasma below $20 \mathrm{mmol} /$ liter was considerably higher in patient $l(5.1 \%)$ and patient $2(11.6 \%)$ than in patients $3-5(1.7 \%)$, reflecting the higher urinary losses of bicarbonate in the former two patients (Table 2). From these figures, daily excretion rates of bicarbonate can be predicted roughly by extrapolation. The estimates are 4.0 in patient $1,10.3$ in patient 2 , and $0.64-0.87 \mathrm{mmol} / \mathrm{kg} / 24 \mathrm{hr}$ in patients $3-5$. These figures are slightly lower than the daily doses of alkali administered by mouth to each patient (Table 1).

Higher urinary excretion rates of bicarbonate in patients 1 and 2 cannot be explained by differences in urine flow, as the flow was similar in all five patients. Mean urine flow was $5.0-6.7 \%$ (range $2.4-14.4 \%$ ) of the glomerular filtration rate in each patient. Fluid administration during the studies was kept low in order to avoid significant expansion of extracellular fluid volume; increase in body weight never exceeded $350 \mathrm{~g}$ or $1.7 \%$. Highest urine flow rates were associated with only a minor increase in excretion of bicarbonate of less than $20 \mu \mathrm{mol} / 100 \mathrm{ml} \mathrm{GF}$ above mean values.

The percentage of filtered potassium excreted in the urine $\left(C_{K} / C_{i n} \times 100\right.$ did not change significantly during infusion of bicarbonate in patient 1 (mean value $34 \%$, range $31-37 \%$ ) and in three patients with classic distal RTA (means $23 \%$, range 14 $37 \%)$, despite falling concentrations of potassium in serum ob-

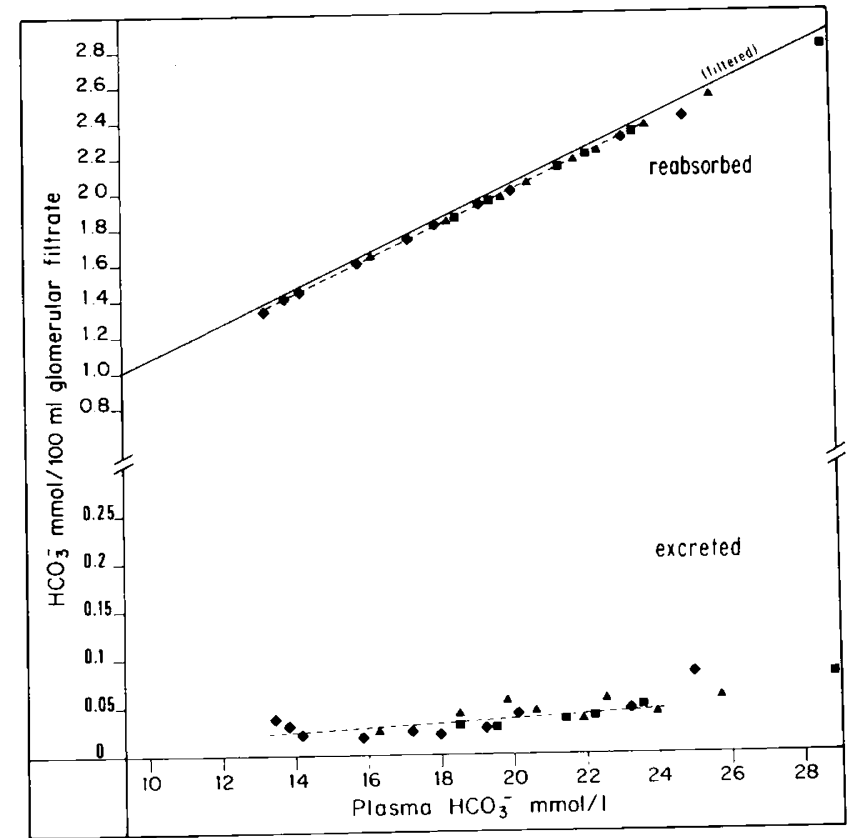

Fig. 2. Excretion and reabsorption of filtered bicarbonate in three patients with classic RTA. $\diamond$, patient $3 ; \mathbf{\square}$, patient 4 : $\mathbf{\Delta}$, patient 5 .

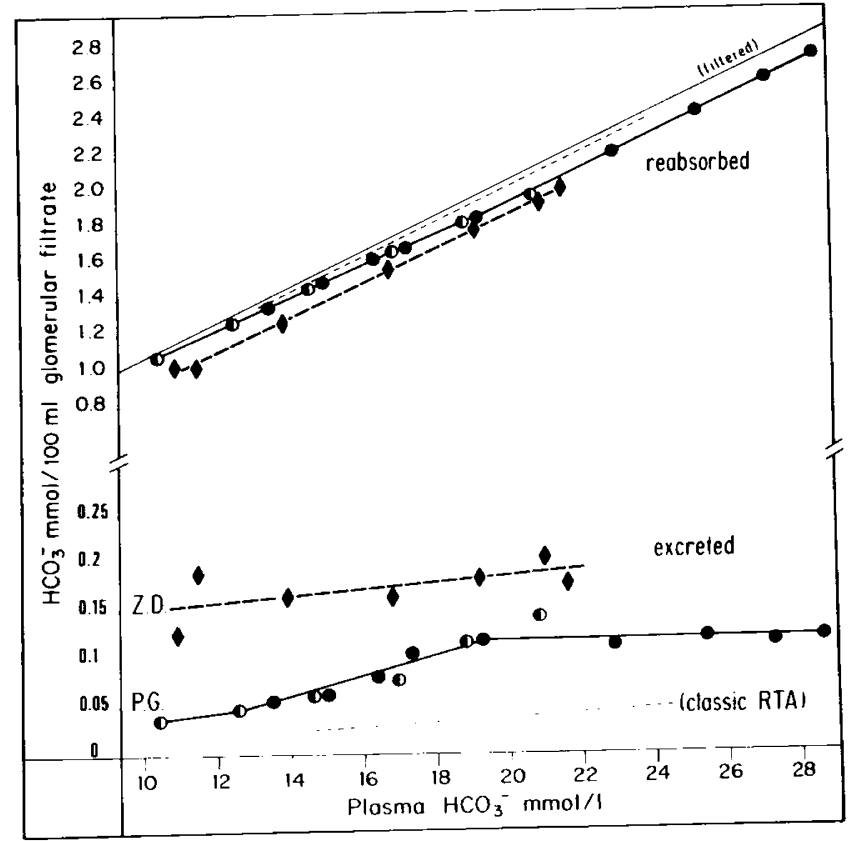

Fig. 3. Excretion and reabsorption of filtered bicarbonate in two patients with distal RTA and bicarbonate wasting. $\mathcal{O}$, first; $\bullet$, second study in patient $I(P G)$; patient $2(Z D)$. The thin broken lines correspond to those in Figure 2.

served during these studies (patients $3-5: \mathrm{K}^{+}=3.0-4.0 \mathrm{mmol} /$ liter at the beginning, $2.4-2.9 \mathrm{mmol} /$ liter at the end of the study; patient $l: 3.0$ and $2.2 \mathrm{mmol} /$ liter, respectively, Table 3 ). In patient 2 , serum potassium could be determined only at the end of the study. Although $\mathrm{K}^{+}$was still $3.7 \mathrm{mmol} /$ liter, fractional excretion $\left(\mathrm{C}_{\mathrm{K}}+/ \mathrm{C}_{\mathrm{in}}\right) \times 100$ was low $(13 \%)$.

\section{ACID EXCRETION}

Patients $l$ and 2 . The value of TA excreted in the urine was near 0 in patient $l$, and thus similar to that in patients 3-5 (ranging from +2 to $-9 \mu \mathrm{mol} / 100 \mathrm{ml} \mathrm{GF}$ (Table 3 ). It was strikingly negative in patient $2(-19$ to $-59 \mu \mathrm{mol} / 100 \mathrm{ml} \mathrm{GF})$. Excretion of ammonium (mean value $14.9 \mu \mathrm{mol} / 100 \mathrm{ml} \mathrm{GF}$ in patient / (Table 3 ), and 18.9 in patient 2 ; range 5-24) was slightly lower than in patients 3-5 and remained fairly stable throughout the study.

In striking contrast to patients 3-5, values of net acid excretion were strongly negative throughout the studies, especially in patient 2 (Tables 2 and 3, Fig. 4). The highest value of net acid excretion obtained in the latter $(-157 \mu \mathrm{mol} / 100 \mathrm{ml}$ GF) was still far lower than any value obtained in the other patients. As a result, net loss of base was considerably more severe in this patient than in the others. Minimal values of urine $\mathrm{pH}$ observed during the bicarbonate studies were considerably higher $(>7.3)$ in patients $I$ and 2 than in the other three patients (Table 2).

Patients 3-5. Values of excretion of titratable acid were initially close to 0 and became slightly negative during infusion of bicarbonate (range from +2 to $-15 \mu \mathrm{mol} / 100 \mathrm{ml} \mathrm{GF}$ ). Similarly, excretion of ammonium decreased slightly during the study (mean $29.4 \mu \mathrm{mol} / 100 \mathrm{ml} \mathrm{GF}$, range $15-20$ ). Thus, values of net acid excretion, which were slightly positive at the beginning, became gradually negative during the study (Table 2, Fig. 4). The curves of net acid excretion for patients 4 and 5 are almost identical, and that of patient 3 is very similar, although slightly shifted to the left.

\section{DISCUSSION}

The results of the bicarbonate titration studies performed in patients 3-5 resemble closely those obtained in other patients with classic distal RTA $(23,30,32,39)$. There is a constant but insignificant loss of bicarbonate in the urine; only approximately 
Table 3. Bicarbonate titration study in distal renal tubular acidosis with bicarbonate wasting (patient 1 , second study) ${ }^{1}$

\begin{tabular}{|c|c|c|c|c|c|c|c|c|c|c|c|c|c|c|c|}
\hline \multirow{3}{*}{$\begin{array}{l}\text { Time, } \\
\text { min }\end{array}$} & \multicolumn{3}{|c|}{ Blood } & \multicolumn{3}{|c|}{$\begin{array}{l}\text { Serum, } \\
\text { mmol/ } \\
\text { liter }\end{array}$} & \multicolumn{6}{|c|}{ Urine } & \multirow[b]{2}{*}{$C_{\text {in }}$} & \multirow[b]{2}{*}{$\mathrm{C}_{\mathrm{PAH}}$} & \multirow{3}{*}{$\begin{array}{c}\mathrm{C}_{\mathrm{HCO}{ }^{-}} \\
\mathrm{C}_{\mathrm{in}}, \\
\%\end{array}$} \\
\hline & & & $\mathrm{HCO}_{3}{ }^{-}$ & & & & & & $\mathrm{HCO}_{3}^{-}$ & TA & $\mathrm{NH}_{4}^{+}$ & NAE & & & \\
\hline & $\mathrm{pH}$ & $\mathrm{mm} \mathrm{Hg}$ & liter & $\mathrm{Na}^{+}$ & $\mathrm{K}^{+}$ & $\mathrm{Cl}^{-}$ & $\mathrm{ml} / \mathrm{min}$ & $\mathrm{pH}$ & \multicolumn{4}{|c|}{$\mu \mathrm{mol} / 100 \mathrm{ml} \mathrm{GF}$} & \multicolumn{2}{|c|}{$\mathrm{ml} / \mathrm{min}$} & \\
\hline $\begin{array}{l}-65 \\
-60^{2} \\
-55^{3}\end{array}$ & 7.29 & 30.4 & 14.2 & 135 & 3.0 & 114 & & & & & & & & & \\
\hline $\begin{array}{r}0-30 \\
33^{4}\end{array}$ & 7.29 & 29.0 & 13.5 & 135 & 3.0 & & 0.70 & 7.66 & 51 & -7 & 10 & -48 & 22.5 & 144 & 3.8 \\
\hline $30-54$ & 7.28 & 33.0 & 15.0 & 137 & 3.0 & & 0.83 & 7.71 & 59 & -7 & 10 & -56 & 25.5 & 141 & 3.9 \\
\hline 54.80 & 7.32 & 32.5 & 16.4 & 137 & 3.0 & & 0.92 & 7.70 & 78 & -7 & 10 & -75 & 26.4 & 137 & 4.8 \\
\hline $80-105$ & 7.35 & 31.9 & 17.3 & 139 & 2.8 & 110 & 2.24 & 7.70 & 102 & 0 & 18 & -84 & 34.1 & 167 & 5.9 \\
\hline $105-130$ & 7.37 & 34.5 & 19.3 & 139 & 2.8 & & 2.28 & 7.59 & 109 & -4 & 20 & -93 & 32.3 & 170 & 5.6 \\
\hline $130-156$ & 7.40 & 32.0 & 19.2 & 139 & 2.6 & & 3.65 & 7.38 & 120 & +1 & 26 & -93 & 30.6 & 153 & 6.3 \\
\hline $156-184$ & 7.42 & 37.0 & 23.3 & 140 & 2.5 & & 1.82 & 7.64 & 113 & +2 & 19 & -92 & 27.3 & 131 & 4.9 \\
\hline $184 \quad 210$ & 7.45 & 34.0 & 22.9 & 140 & 2.5 & & 1.46 & 7.78 & 110 & -7 & 13 & -104 & 34.8 & 182 & 4.8 \\
\hline $210-235$ & 7.46 & 33.4 & 23.0 & 140 & 2.3 & & 1.40 & 7.80 & 114 & -5 & 13 & -106 & 31.1 & 151 & 5.0 \\
\hline $235-263$ & 7.49 & 34.4 & 25.4 & 141 & 2.3 & & 1.89 & 7.75 & 118 & -6 & 15 & -109 & 37.3 & 182 & 4.6 \\
\hline $263-291$ & 7.49 & 36.5 & 27.3 & 141 & 2.2 & & 1.82 & 7.65 & 115 & -9 & 14 & -110 & 34.2 & 157 & 4.2 \\
\hline $291 \cdot 315$ & 7.47 & 40.6 & 28.6 & 141 & 2.2 & 102 & 1.17 & 7.90 & 118 & -9 & 11 & -116 & 31.6 & 120 & 4.1 \\
\hline
\end{tabular}

${ }^{1}$ Age $32 / 12$, surface area $0.53 \mathrm{~m}^{2}$. Weight was $12.0 \mathrm{~kg}$ at the beginning and $12.1 \mathrm{~kg}$ at the end of the study. TA: titratable acid; NAE: net acid excretion.

${ }^{2}$ Priming injection: $4.8 \mathrm{ml}$ polyfructosan $25 \%, 0.5 \mathrm{ml}$-aminohippurate (PAH) $20 \%$, and $4.7 \mathrm{ml} \mathrm{NaCl} 0.9 \%$.

${ }^{3}$ Start infusion 1: polyfructosan $10 \%, \mathrm{PAH} 2 \%$, and $\mathrm{NaCl} 0.45 \%$, at $0.21 \mathrm{ml} / \mathrm{min}$.

${ }^{4}$ Start infusion II: $\mathrm{NaHCO}_{3}(0.3 \mathrm{~mol} /$ liter $)$, at $1.5 \mathrm{ml} / \mathrm{min}$.

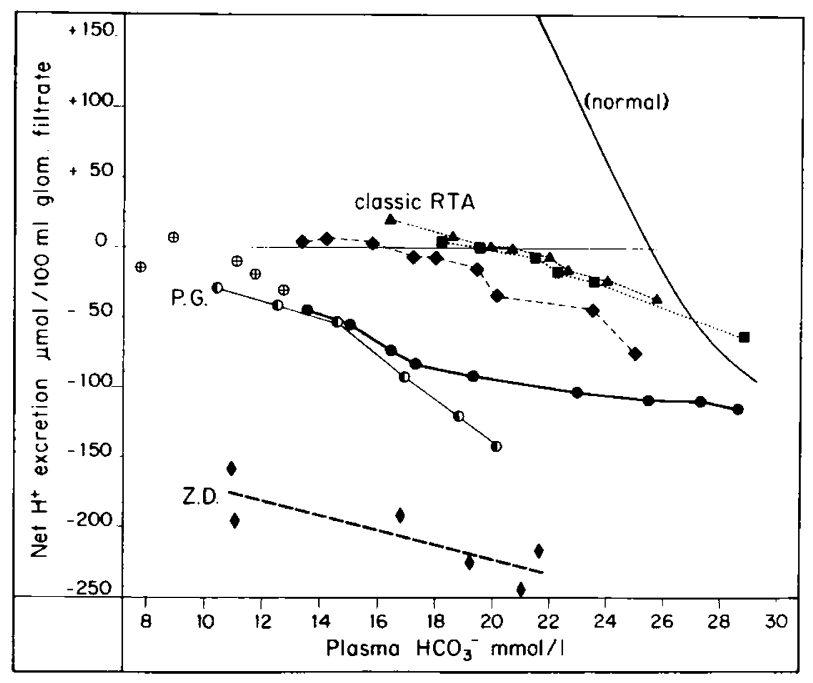

Fig. 4. Net acid excretion during the bicarbonate titration studies in five patients with distal RTA. The same symbols are used as in Figures 2 and 3 . $\oplus$ were random estimations obtained in patient $l$ at episodes of metabolic acidosis. The normal curve is from Reference 28.

$2 \%$ of the filtered load of bicarbonate is excreted. In contrast to the results obtained by Rodriquez Soriano et al. (32), we observed no great increase in urinary excretion of bicarbonate at high plasma concentrations; even at a plasma $\mathrm{HCO}_{3}{ }^{-}$of $28.8 \mathrm{mmol} / \mathrm{liter}$, bicarbonate excretion was only twice the mean value. This discrepancy is most likely explained by the fact that expansion of extracellular fluid volume, which leads to diminished reabsorption of bicarbonate (29), was apparently greater in their study than in ours (see (26)). Positive values of net acid excretion have been found consistently in patients with classic RTA during episodes of metabolic acidosis $(23,30,32,39)$, yet net acid excretion during infusion of bicarbonate has not been studied systematically. As compared with the situation in the normal subject (28), the curves of net acid excretion are shifted to the left and are flatter. The similarity of these results and of the clinical findings suggest that patients 3-5 are affected by the same entity referred to as the classic type of distal RTA $(1,4)$. Inner ear deafness is not infrequently encountered as an associated anomaly in this syndrome $(26,35)$. The exact nature of the metabolic defect is not known (37). Failure of the cells of the distal nephron to secrete hydrogen ions is considered to be the most likely cause of classic RTA (15).

In contrast, the two other patients ( $I$ and 2$)$ differ in various respects from those with classic RTA. Both presented with very early and severely decompensated acidosis showed obvious bicarbonate wasting. In the first patient $(P G)$, radiologically proven nephrocalcinosis was already present at 7 weeks of age, which is earlier than has so far been recorded in patients with classic RTA. Fractional excretion of bicarbonate $\left(\mathrm{C}_{\mathrm{HCO}_{3}}{ }^{-} / \mathrm{C}_{\mathrm{in}}\right) \times 100$ remained higher $(5.1 \%)$ than in other patients with classic RTA. This difference cannot be explained by the age of this patient, since the value found by McSherry et al. (23) in a 10-month-old infant with classic RTA (1.7\%) corresponds to that found in adult patients. The same authors (23) described two patients similar to patient $I$ for whom they used the term of "bicarbonate wasting classic RTA." Clinical signs of RTA were usually severe in both their patients at a very early age. Fractional excretion of bicarbonate remained exceptionally high $(4-4.6 \%)$ even at $26-28$ months of age. As in our first patient, the absence of G-6-PD activity in red blood cells was observed in one of their two patients (45).

Rodriquez Soriano et al. (34) have reported recently three infants with bicarbonate wasting distal RTA. As urinary losses of bicarbonate diminished with increasing age and the patients later resembled those with classic RTA, the authors suggested that bicarbonate wasting is a transient age-related phenomenon occurring in the first year of life. Although this might be true in some cases, bicarbonate wasting is certainly not a constant finding in this disorder, since patients with classic RTA rarely show severe clinical manifestations of acidosis during infancy. Furthermore, 
bicarbonate wasting could not be demonstrated in the 10-monthold infant with classic RTA mentioned above (23). The finding of persistent bicarbonate wasting in patient $l$ even at 4 years of age seems to distinguish this case from those reported by Rodriquez Soriano et al. (34).

The pathophysiologic mechanism of bicarbonate wasting in distal RTA cannot be elucidated by bicarbonate titration studies alone. During hypotonic saline diuresis, fractional reabsorption of sodium at the proximal tubule was found by Rodriquez Soriano et al. (34) to be significantly lower than in control infants. They concluded from this observation that an impairment of proximal tubular function was responsible for the bicarbonate wasting. According to a different hypothesis (23), bicarbonate wasting in distal RTA could simply be the result of a more severe defect of the distal nephron, although basically not different from classic RTA. This hypothesis is based on the observation that the urine $\mathrm{pH}$ in these cases has been consistently higher (usually $>7.0$ ) than in patients with classic type. Until more is known about the exact mechanism of bicarbonate wasting, it seems preferable not to use the terms of "combined" or "mixed" proximal and distal RTA in this group of patients.

Sharpira et al. (38) have recently described an inactive mutant of red blood cell carboanhydrase $B$ in three members of a large kindred who manifested infantile RTA, apparently of the distal type, and nerve deafness. The same family was reported by Cohen et al. (8); unfortunately, no bicarbonate titration studies were performed. Since alkali requirements in the propositus were very high $(20 \mathrm{mmol} / \mathrm{kg} / 24 \mathrm{hr})$, this patient seems to be affected by a bicarbonate wasting variant and not by the classic type of RTA. On the other hand, carboanhydrase $B$ activity has been found to be normal in patients with classic RTA (2). The patient, described by Donckerwolcke et al. $(10,11)$, who showed very severe proximal RTA uninfluenced by administration of a carboanhydrase inhibitor, probably represents a separate entity.

In contrast to the foregoing patients, the tubular defect in the second patient $(Z D)$ was transient, although he had demonstrated a more severe degree of bicarbonate wasting. Whereas recovery in proximal RTA may occur, both in the primary and the secondary groups (26), it is definitely unusual in distal RTA. Nevertheless, the following arguments reveal strong evidence that patient 2 had distal and not proximal RTA: (l) the rate of excretion of bicarbonate was hardly affected by gross changes in concentrations of plasma bicarbonate, whereas in proximal RTA any increase of the filtered load is accompanied by an almost parallel increase in excretion of bicarbonate: (2) not even a theoretical threshold for re-absorption of bicarbonate (26) could be defined in spite of very low plasma bicarbonate concentrations. The etiology of the transient acidification defect in this patient remains unknown. Similarly, initial hypercalcemia, which disappeared after simple correction of acidosis, is not clarified. Incrimination of ampicillin, which had produced an allergic rash several weeks before admission, is highly speculative. Primary hyperparathyroidism, which could have explained both hypercalcemia and bicarbonate wastage (25), was excluded by low serum concentration of parathyroid hormone. Overdosage of vitamin $\mathrm{D}$, which could have been a cause of hypercalcemia, is extremely unlikely in view of the negative history, normal calcium excretion in the urine, and slight osteoporosis. Could RTA have been the cause of hypercalcemia, or vice versa? It seems unlikely that RTA was the result of (idiopathic) hypercalcemia, since the severity of acidosis was out of proportion to the increase of serum calcium. On the other hand, there is no evidence to suggest that hypercalcemia was the result of RTA. The finding of normal value of parathyroid hormone after correction of hypercalcemia indicates that response of this hormone to serum concentration of calcium was not disturbed. This association of infantile hypercalcemia and acidosis has been noted before $(6,21)$.

The observation of spontaneous cure of the tubular defect in one of our cases with bicarbonate wasting distal RTA is intriguing. In the early 1950 "s, a syndrome called "transient infantile RTA" (Lightwood's syndrome) was frequently observed $(3,6,12,17,19$. 21, 40); after 1954 its incidence declined dramatically (20). Tue patients reported, almost exclusively infants, presented with moderate to severe metabolic acidosis. Of these, most recovered within a few months, with the exception of a few infants who succumbed to intercurrent illnesses. No definitive etiology was ever found, but overdosage by vitamin D was suspected in some cases. Excretion of bicarbonate in the urine persisted even at low serum concentrations, and urine $\mathrm{pH}$ almost never fell below 6.0. Therapeutic dosage of alkali ranged from 0 to 25 (usually around 10) $\mathrm{mEq} / \mathrm{kg} / 24 \mathrm{hr}$. Since the tubular defect has never been defined properly, its classification has remained controversial. Transient infantile RTA is considered by some as an example of distal (37) and by others of proximal type (26) RTA. Patient 2 is the first documented infant with this syndrome in whom the acidification defect has been defined. However, it might well be that transient infantile RTA is a heterogenous syndrome and that bicarbonate wasting distal RTA represents only one variant.

Considering both clinical aspects and results of bicarbonate titration studies in patients with distal RTA, we would tentatively propose the following classification: (l) persistent type without bicarbonate wasting (classic RTA): (2) persistent type with bicarbonate wasting; (3) transient type; and, (4) other types. The transient type might correspond to Lightwood's syndrome of transient infantile RTA.

\section{SUMMARY}

Bicarbonate titration studies were carried out on two patients with bicarbonate wasting distal RTA and on three patients with classic distal RTA. The acidification defect was permanent except in one patient with bicarbonate wasting distal RTA. As compared with the findings in classic distal RTA, urinary excretion of bicarbonate was increased significantly and values of net acid excretion were strongly negative in the two patients with bicarbonate wasting distal RTA, thus accounting for their greater requirements of alkali. Distal RTA is obviously a heterogenous syndrome of which several types can be distinguished: (l) persistent type without bicarbonate wasting (classic type); (2) persistent type with bicarbonate wasting, (3) transient type, and (4) other types. The patient with spontaneous cure of RTA is the first documented case with Lightwood's syndrome of transient infantile RTA in whom the acidification defect has been studied in detail.

\section{REFERENCES AND NOTES}

1. Albright, F., Consolazio, W. V., Coombs, F. S., Sulkowitch, H. W., and Talbott. J. H.: Metabolic studies and therapy in a case of nephrocalcinosis with rickets and dwarfism. Bull. Johns Hopkins Hosp., 66: 7 (1940).

2. Ben-Yoseph, Y.: Personal communication.

3. Buchanan E U and Komrower G. M.: The prognosis of idiopathic renal acidosis in infancy with observations on urine acidification and ammonia production in children. Arch. Dis. Childhood, 33: 532 (1958).

4. Butler, A. M., Wilson, J. L., and Farber, S.: Dehydration and acidosis with calcification at renal tubules. J. Pediat., 8: 489 (1936).

5. Capelli. J. P., Wesson, L. G., Jr., and Aponte, G. E.: The effect of sodium on renal renin and on glucose- 6 phosphate dehydrogenase in the kidneys, salivary glands and adrenal glands. 1. A histochemical and biochemical study Nephron, 5: 106 (1968).

6. Carre I. J. Wood B. S and Smallwood W. C.: Idiopathic renal acidosis in infancy. Arch. Dis. Childhood, 29: 326 (1954).

7. Chan, T. K., Todd, D., and Wong, C. C.: Tissue enzyme levels in erythrocyte glucose-6-phosphate dehydrogenase deficiency. J. Lab. Clin. Med., 66: 937 (1965).

8. Cohen, T., Brand-Auraban, A., Karshai, C., Jacob, A., Gay, I., Tsitsianov, J., Shapiro, T., Jatziv, S., and Ashkenazi, A.: Familial infantile renal tubular acidosis and cogenital nerve deafness: An autosomal recessive syndrome. Clin. Genet., 4: 275 (1973).

9. Conway, E. J.: Microdiffusion Analysis and Volumetric Error, Ed. 4., p. 98 (MacMillan, New York, 1952).

10. Donckerwolcke, R. A., van Stekelenburg, G. J., and Tiddens, H. A.: A case of bicarbonate-losing renal tubular acidosis with defective carboanhydrase activity. Arch. Dis. Childhood, 45: 769 (1970) 
11. Donckerwolcke, R. A., van Stekelenburg. G. J., and Tiddens, H. A.: Therapy of bicarbonate-losing renal tubular acidosis. Arch. Dis. Childhood, 45: 774 (1970).

12. Doxiadis, S. A.: Idiopathic renal acidosis in infancy. Arch. Dis. Childhood, 27: 409 (1952)

13. Fanconi, A., and Prader. A.: Primäre Tubulopathien. I. Ein Fall von idiopathischer renal-tubulärer Acidose (Albright-Syndrom). Helv. Paediat. Acta. 16: 609 (1961).

14. Fischer, J. A., Binswanger, U., Fanconi, A., Illig, R., Baerlocher, K., and Prader, A.: Serum parathyroid hormone concentrations in vitamin $D$ deficiency rickets of infancy: Effects of intravenous calcium and vitamin D. Hormone Metab. Res., 5: 381 (1973).

15. Halperin, M. L., Goldstein, M. B.. Haig, A., Johnson, M. D., and Stinebaugh, B. J.: Studies on the pathogenesis of type I (distal) renal tubular acidosis as revealed by the urinary $\mathrm{pCO}_{2}$ tensions. J. Clin. Invest., 53: 669 (1974).

16. Hastings, A. B., and Sendroy, J. Jr.: The effect of variation in ionic strength on the apparent first and second dissociation constants of carbonic acid. J. Biol. Chem., 65: 445 (1925).

17. Hutchison, J. H., and Macdonald, A. M.: Chronic acidosis in infants due to renal tubular deficiency: Its association with metastatic calcification. Acta Paediat., 40: 371 (1951).

18. Jgrgensen, K.: Titrimetric determination of the net excretion of acid-base in urine. Scand. J. Clin. Lab. Invest., 9: 287 (1957).

19. Latner, A. L.. and Burnard, E. D.: Idiopathic hyperchloremic renal acidosis in infants (nephrocalcinosis infantum): Observations on the site and nature of the lesion. Quart. J. Med., 19: 285 (1950)

20. Lightwood, R., and Butler, N.: Decline in primary infantile renal acidosis: Aetiological implications. Brit. Med. J. I: 855 (1963).

21. Lightwood, R., Payne, W. W., and Black, J. A.: Infantile renal acidosis Pediatrics, 12: 628 (1953)

22. McCrory, W. W.: Developmental Nephrology, p. 96 (Harvard University Press, Cambridge, Mass., 1972).

23. McSherry, E., Sebastian, A., and Morris, R. C., Jr.: Renal tubular acidosis in infants: The several kinds, including bicarbonate-wasting, classic renal tubular acidosis. J. Clin. Invest., 51: 499 (1972).

24. Mertz, D. P., and Sarre, H.: Polyfructosan-S: Eine neue inulinartige Substanz zur Bestimmung des Glomerulusfiltrates und des physiologisch aktiven extracellulären Flüssigkeitsvolumens beim Menschen. Klin. Wschr., 41: 868. (1963).

25. Muldowney, F. P., Carroll, D. V., Donohoe, J. F., and Freaney, R.: Correction of renal bicarbonate wastage by parathyroidectomy. Implications in acid-base homeostasis. Quart. J. Med., 40: 487 (1971)

26. Nash, M. A., Torrado, A. D., Greifer, I., Spitzer, A., and Edelmann, C. M.. Jr.: Renal tubular acidosis in infants and children: Clinical course, response to treatment, and prognosis. J. Pediat., 80: 738 (1972).

27. Natelson, S.: Microtechniques of Clinical Chemistry, Ed. 2, p. 152 (Charles C Thomas, Springfield, III. 1963).

28. Oetliker, O., Chattas, A. J., and Schultz, S. M.: Characterization of renal contribution to acid-base balance in the pediatric age group. Helv. Paediat. Acta., 26: 523 (1971)

29. Purkerson, M. L.. Lubowitz, H., White, R. W., and Bricker, N. S.: On the influence of extracellular fluid volume expansion on bicarbonate reabsorption in the rat. J. Clin. Invest., 48: 1754 (1969).

Copyright (C) 1975 International Pediatric Research Foundation, Inc
30. Reynolds, T. B.: Observations on the pathogenesis of renal tubular acidosis. Amer. J. Med., 25: 503 (1958).

31. Richterich, R. Klinische Chemie: Theorie und Praxis, Ed. 2 (S. Karger, Basel, 1968).

32. Rodriguez-Soriano, J., Boichis, H.. and Edelmann, C. M., Jr.: Bicarbonate reabsorption and hydrogen ion excretion in children with renal tubular acidosis. J. Pediat., 71: 802 (1967).

33. Rodriguez-Soriano, J., Boichis. H., Stark, H., and Edelmann, C. M., Jr.: Proximal renal tubular acidosis. A defect in bicarbonate reabsorption with normal urinary acidification. Pediat. Res., $l: 81$ (1967).

34. Rodriguez-Soriano, J., Vallo, A., and Garcia-Fuentes, M.: Distal renal tubular acidosis in infancy: A bicarbonate wasting state. J. Pediat., 86: 524 (1975).

35. Royer, P.: Acidoses tubulaires primitives. In: P. Royer, R. Habib, H. Mathieu, and M. Broyer: Néphrologie Pédiatrique, p. 60 (Flammarion, Paris, 1973).

36. Schaerer, K., and Antener, I.: Zur Biochemie und Therapie der Cystinose. Ann. Paediat. (Basel), 203: suppl.1 (1964)

37. Seldin, D. W., and Wilson, J. D.: Renal tubular acidosis. In: J. B. Stanbury, J. B. Wyngaarden, and D. S. Fredrickson: The Metabolic Basis of Inherited Disease, Ed. 3, p. 1548 (McGraw-Hill, New York, 1972).

38. Shapira, E., Ben-Yoseph, Y., Eyal, F. G., and Russell, A.: Enzymatically inactive red cell carbonic anhydrase $B$ in a family with renal tubular acidosis. J. Clin. Invest., 53: 59 (1974).

39. Smith. L. H., Jr., and Schreiner, G. E.: Studies on renal hyperchloremic acidosis. J. Lab. Clin. Med., 43: 347 (1954).

40. Stapleton, T.: Idiopathic renal acidosis in an infant with excessive loss of bicarbonate in the urine. Lancet, $i: 683$ (1949).

41. Vries, L. A., de, and Daetselaar, J. J.: Bepaling van creatinine in serum volgens Folin. In: E. Gorter and W. C. de Graaf: Klinische Diagnostik, Ed. 7, p. 278 (Stenfert Kroese, Leiden, 1955).

42. The clearance of polyfructosan, a polyfructoside like inulin, is identical with that of inulin (24) and is subsequently expressed as $C_{i n}$

43. Measurement of parathyroid hormone (PTH) was kindly performed by Dr. J. A. Fischer, Department of Orthopaedic Surgery, University of Zürich, as described earlier (14).

44. This patient has been reported in detail by Fanconi and Prader (13).

45. This association has not been recorded in classic RTA. In G-6-PD deficiency. activity of this enzyme may also be decreased in the kidney (7). Renal activity of G-6-PD has been shown to be closely related to sodium balance in the rat (5). A relationship between G-6-PD deficiency and bicarbonate wasting in patients with distal RTA might thus be possible.

46. Presented in part at the Seventh Annual Meeting of the European Society for Pediatric Nephrology, Strbské Pleso, September 10-13, 1973, and at the Annual Meeting of the Swiss Society of Nephrology, Bern. November 30 , 1974.

47. Informed consent was obtained from patient 5 and the parents of the other patients before the study.

48. We wish to thank Professor A. Prader, Children's Hospital of Zürich, for his criticism and encouragement, and V. Fritz-Mikulska, M.D., and K. Baerlocher, M.D., for referral of patient 3. The skillful technical assistance of Z. Manicová, M.D., is gratefully acknowledged.

49. Requests for reprints should be addressed to: E. P. Leumann, M.D., UniversitatsKindurklinik, Steinwiesstrasse 75, CH-8032 Zürich (Switzerland)

50. Accepted for publication June 12,1975. 